\title{
ANALISIS PENILAIAN KINERJA BANK SYARIAH BERDASARKAN INDEKS MAQASID SHARI'AH \\ (Studi Kasus pada 9 Bank Umum Syariah di Indonesia Tahun 2015)
}

\author{
Anton Sudrajat \\ Jurusan Syariah Dan Ekonomi Islam STAIN Ponorogo \\ E-mail: Antonsudrajat83@gmail.com \\ Amirus Sodiq \\ Jurusan Syariah Dan Ekonomi Islam STAIN Kudus \\ E-mail: sodiqamirus@gmail.com
}

\begin{abstract}
To assess if the aims of Islamic banking establishment has been appropriated with maqashid syariah, this assessment needs performance measurement based on maqashid syariah that was adopted from Abu Zahrah's concept of maqashid syariah. This article aims to analyze the performance measurement of syariah commercial banks in Indonesia based on maqashid syariah index. This research results the rating of syariah commercial banks as follows: 1) Bank Panin Syariah, 2) BCA Syariah, 3) bank Muamalat, 4) Bukopin Syariah, 5) BRI Syariah, 6) BNI Syariah, 7) Bank Syariah Mandiri, 8) Maybank Syariah, 9) Bank Mega Syariah.
\end{abstract}

Keywords: Performance, Maqashid Syariah Index, Syariah Commercial Bank

\section{A. Pendahuluan}

Tujuan ekonomi Islam adalah pencapaian maqasid syariah dengan cara mewujudkan keadilan dan keseimbangan masyarakat. Bank syariah merupakan subsistem ekonomi Islam. Maka seharusnya tujuan bank syariah adalah menjunjung tinggi tujuan sosial, mempromosikan nilai-nilai Islam kepada seluruh stake 
holder, memberikan kontribusi kesejahteraan sosial, mendukung keberlangsungan ekonomi, dan berusaha mengentaskan kemiskinan (Dusuki, 2008: 134). Namun pada kenyataannya, banyak kritik yang ditujukan kepada bank syariah yang cenderung berorentasi pada keuntungan bukan berdasarkan tujuan sosial jika dilihat dari perspektif maqasid syariah (Mohammad \& Shahwan, 2013).

Untuk memberikan penilaian apakah tujuan pendirian bank syariah sudah selaras dengan maqashid syariah, maka diperlukan penilaian kinerja secara khusus berdasarkan maqashid syariah. Karena menurut Badreldin (2009) selama ini pengukuran kinerja bank syariah dilakukan dengan menggunakan rasio keuangan yang mengadopsi dari pengukuran kinerja bank konvensional.

Sedangkan menurut Mohammed, dkk (2008: 17) terdapat ketidak sesuaian penggunaan ukuran kinerja bank konvensional karena terdapat perbedaan indikator kinerja bank konvensional dengan tujuan bank syariah yang lebih luas, sehingga stake holder bank syariah tidak dapat melihat perbedaan secara jelas antara bank syariah dengan bank konvensional. Berdasarkan latar belakang masalah ini, maka rumusan masalah dalam penelitian ini adalah bagaimana analisis penilaian kinerja bank umum syariah di Indonesia berdasarkan indeks maqasid syariah?

\section{B. Kajian Pustaka}

Salah satu tantangan dalam perkembangan perbankan syariah adalah kurangnya alat pengukuran kinerja keuangan yang sesuai dengan karakteristik bank syariah. Sebagai solusinya, banyak peneliti yang mengukur kinerja bank syariah dengan menggunakan pendekatan ukuran kinerja bank konvensional melalui rasio-rasio keuangan. Secara umum, banyak peneliti yang menggunakan rasio Return on Aset (ROA) dan Return on Equity (ROE) untuk mengukur kinerja bank Islam, seperti: 
Bashir (2001), Choong, dkk (2012), Zeitun (2012), Hidayat \& Abduh (2012).

Pengukuran kinerja bank syariah dengan menggunakan rasio-rasio keuangan yang diadaptasi dari perbankan konvensional sebagaimana telah dilakukan oleh banyak peneliti belum mampu menunjukkan penilaian kinerja bank syariah sebenarnya sebagai subsistem ekonomi Islam yang bertujuan mewujudkan keadilan dan keseimbangan masyarakat sebagai perwujudan dari tujuan syariah (maqashid syariah). Sehingga kebanyakan perbankan syariah terkesan berorentasi pada keuntungan (profit oriented) bukan berdasarkan tujuan sosial (Mohammad \& Shahwan, 2013).

Sehubungan dengan hal tersebut, Mohammed, dkk (2008) mengembangkan model pengukuran kinerja bank syariah berdasarkan maqashid syariah yang diadaptasi dari rumusan maqasid syariah milik oleh Abu Zahrah (1997) dengan mengklasifikasikan konsep maqasid syariah menjadi: 1) Mendidik individu, 2) Menegakkan keadilan, dan 3) Memelihara kemaslahatan. Selanjutnya Mohammed, dkk (2008) menggunakan metode Sekaran untuk membreak down konsep maqasid syariah menjadi indikator-indikator yang memiliki elemen-elemen yang kemudian diproksikan dengan rasio keuangan kinerja bank Islam sehingga menghasilkan maqasid syariah index yang dicapai oleh suatu bank syariah (Mohammed, dkk, 2008).

Pengembangan indeks maqasid syariah sebagai penilaian kinerja bank syariah telah dilakukan pengujian secara empiris oleh Mohammed, dkk (2008) untuk menilai kinerja 6 bank Islam di Malaysia, Bangladesh, Indonesia, Bahrain, Yordania, dan Sudan. Pengujian ini menghasilkan pencapaian rangking indeks maqashid bank Islam masingmasing negara dengan pencapaian nilai tertinggi indeks maqashid syariah diraih oleh sampel bank Islam Sudan. Selain itu, Mohammed \& Taib juga melakukan studi 
perbandingan ukuran kinerja bank Islam berdasarkan Performance Measures based on Maqasid Syariah (PMMS) dengan Conventional Bank Performance Measure (CBPM) terhadap 24 sampel bank Islam. Temuan penelitian ini adalah bahwa rata-rata kinerja bank syariah lebih tinggi jika diukur dengan pendekatan Performance Measures based on Maqasid Syariah (PMMS) dibandingkan dengan pendekatan Conventional Bank Performance Measure (CBPM) (Mohamed dan Taib, 2015).

Penggunaan maqashid syariah Indeks yang dikembangkan oleh Mohammed, dkk (2008) juga digunakan oleh beberapa peneliti yang lain seperti Antonio, dkk (2012) yang menggunakan indeks maqasid syariah untuk menganalisis kinerja bank Islam di Indonesia dan Jordania selama periode 2008-2010. Hasil penelitian menunjukkan terdapat 2 (dua) bank syariah di Indonesia yang memperoleh indeks maqasid syariah tertinggi (Antonio dkk, 2012). Selain itu, Jazil \& Syahrudin (2013) juga menggunakan pendekatan maqasid al-Shari' ah yang dikembangkan oleh Mohammed, dkk (2008) untuk menganalisis kinerja bank Islam di Indonesia dan Malaysia periode 2007-2011. Hasilnya menempatkan 2 (dua) bank syariah di Indonesia pada urutan teratas dalam pencapaian maqashid syariah indeks.

\section{Landasan Teori}

Secara bahasa Maqashid Syariah terdiri dari 2 (dua) kata, maqashid dan syariah. Kata maqashid merupakan bentuk jamak dari maqshad yang berarti maksud dan tujuan, sedangkan syariah secara bahasa mempunyai arti jalan ke sumber mata air, yakni jalan lurus yang harus diikuti oleh setiap muslim. Syariat merupakan jalan hidup muslim, syariat memuat hukum-hukum Allah yang ditetapkan untuk manusia agar dipedomani untuk mencapai kebahagian hidup di dunia maupun di akhirat (Asmawi, 2012: 108). Maka maqashid syariah dapat dipahami sebagai tujuan- 
tujuan yang hendak dicapai dari suatu penetapan hukum (Jaya, 1996: 5).

Auda (2008: 2) mendefinisikan maqasid syariah sebagai tujuan atau maksud dari pemberlakuan hukum Islam. Sedangkan menurut 'Alal al-Fasi, maqasid syariah adalah tujuan umum dari pemberlakuan syariat dan beberapa rahasia yang terkandung dalam setiap produk hukumnya. Tujuan umum pemberlakuan syariat adalah memakmurkan kehidupan di bumi, menjaga ketertiban di dalamnya, senantiasa menjaga stabilitas kemaslahatan alam dengan tanggung jawab manusia menciptakan lingkungan yang sehat, berlaku adil dan berbagai tindakan yang dapat bermanfaat bagi seluruh lapisan penghuni bumi (FKI Ahla Shuffah, 2013: 2).

Tujuan penetapan hukum atau yang dikenal dengan istilah maqashid syariah memiliki inti teori adalah untuk mewujudkan kebaikan sekaligus menghindarkan keburukan, atau menarik manfaat dan menolak mudharat. Istilah yang sepadan dengan inti dari maqashid syariah adalah maslahah, karena penetapan hukum dalam Islam harus bermuara kepada kemaslahatan (Shidiq, 2009: 118). Menurut Asy-Syatibi (1975: 3-4) bahwa maqasid dapat dilihat dari 2 (dua) bagian, yaitu: tujuan al-Syari' (qasd alsyari' ) dan tujuan mukallaf (qasd al-mukalaf). Berdasarkan tujuan al-Syari' bahwa tujuan awal penetapan hukum syariah adalah untuk kemaslahatan manusia di dunia dan di akhirat secara bersama-sama.

Untuk mewujudkan kemashlahatan tersebut AsySyathibi (1975: 2-3) membagi maqashid menjadi tiga tingkatan, yaitu: maqashid dharûriyât, maqashid hâjiyat, dan maqashid tahsînât. Asy-Syathibi menjelaskan lebih rinci lima kategori maqashid dharûriyât, yaitu : (1) menjaga agama (hifzh ad-din); (2) menjaga jiwa (hifzh an-nafs); (3) menjaga akal (hifzh al- aql); (4) menjaga keturunan (hifzh annasl); (5) menjaga harta (hifzh al-mal). Penjelasan tiga tingkatan maqasid adalah sebagai berikut: 
Sedangkan menurut Abu Zahrah (1997: 364) bahwa keberadaan syariat Islam adalah sebagai rahmat bagi manusia, sehingga tujuan-tujuan yang hendak dicapai dalam penetapan hukum syariat (maqasid syariah) meliputi:

1. Mendidik individu (Tahdhib al fard), yaitu agar masingmasing individu menjadi sumber kebaikan bagi komunitasnya bukan sebaliknya menjadi sumber keburukan bagi setiap manusia. Sehingga berbagai macam ibadah yang disyariatkan bertujuan untuk melatih jiwa agar tidak cenderung pada keburukan yang menghasilkan tindakan dholim, keji, dan munkar terhadap orang lain sehingga tercipta keharmonisan dalam masyarakat.

2. Menegakkan keadilan (Iqamah al 'Adl), yaitu mewujudkan keadilan dalam semua bidang kehidupan manusia, dalam bidang muamalah dengan menghormati hak dan melaksanakan kewajiban antar pihak yang bermuamalah, karena di mata hukum semua manusia adalah sama tidak ada perbedaan antara yang kaya dan miskin, yang kuat dan yang lemah memiliki kewajiban yang sama yaitu menghormati hak orang lain dan melaksanakan kewajibannya.

3. Menghasilkan kemaslahatan (Jalb al Maslahah), yaitu menghasilkan kemaslahatan umum bukan kemaslahatan yang khusus untuk pihak tertentu. Kemaslahatan berdasarkan hukum-hukum syariah dan nash-nash agama merupakan kemaslahatan yang sebenarnya karena mengarah pada penjagaan terhadap agama, jiwa, harta, akal, dan keturunan.

Selanjutnya, teori maqashid syariah Abu Zahrah tersebut dikembangkan oleh Mohammed, dkk (2008) menjadi model penilaian kinerja bank Islam berdasarkan maqasid syariah. Ide dasar pengembangan model ini berasal dari ketidaksesuaian penggunaan model pengukuran kinerja berdasarkan ukuran konvensional sehingga menjadikan stake holder bank Islam tidak dapat melihat secara jelas 
perbedaan tujuan yang hendak dicapai oleh bank Islam dan bank konvensional. Karena bank Islam merupakan subsistem ekonomi Islam, sedangkan ekonomi Islam bertujuan untuk mencapai maqasid syariah, maka seharusnya tujuan bank Islam adalah mencapai maqasid syariah.

Mohammed, dkk (2008) menggunakan metode Sekaran (2000) untuk membreak down konsep maqasid syariah Abu Zahrah menjadi dimensi-dimensi yaitu berupa perilaku yang dapat diobservasi. Kemudian masing-masing dimensi dibreakdown menjadi elemen-elemen yaitu berupa perilaku yang dapat diukur dengan rasio keuangan bank syariah. Penjelasannya dapat dilihat dalam gambar 1.1 berikut:

Gambar 1.1 Kerangka Operasional Tujuan, Dimensi, dan Elemen Maqashid Syariah

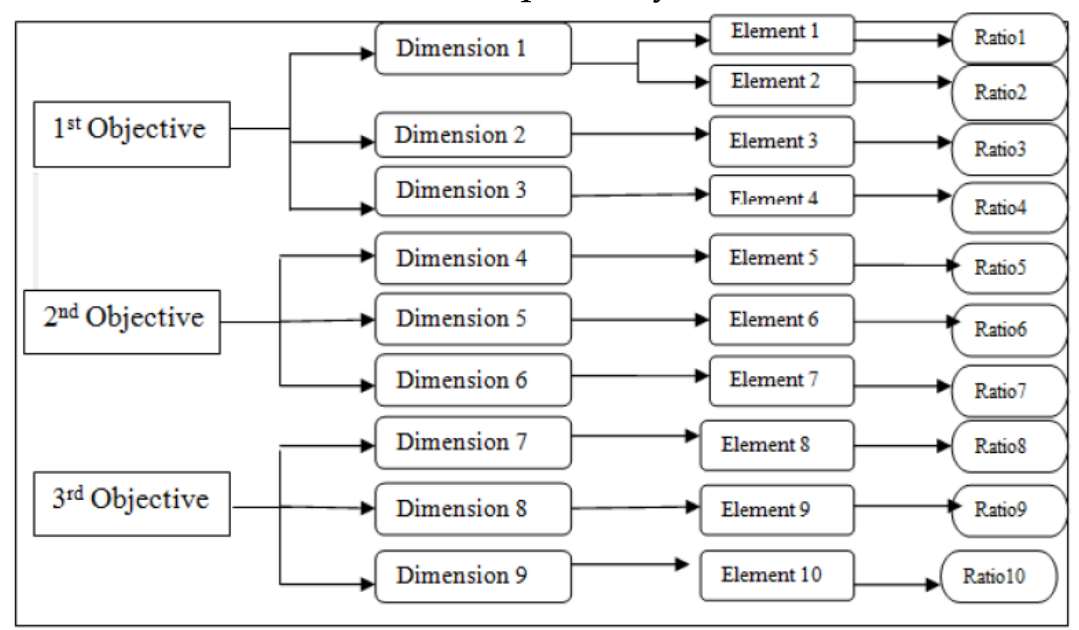

Sumber: Mohammed \& Taib (2015)

Selain itu, untuk memperoleh bobot rasio masingmasing konsep (tujuan) Mohammed, dkk (2008) menggunakan 2 (dua) cara, yaitu: kuisioner dan wawancara terhadap ahli hukum syariah dari Timur Tengah dan Malaysia yang benar-benar memahami bank syariah dan bank konvensional untuk kepentingan verifikasi ukuran 
kinerja. Rata-rata bobot yang ditentukan oleh para ahli syariah adalah sebagai berikut:

Tabel 1.1 Bobot Masing-masing Tujuan dan Elemen

\begin{tabular}{|c|c|c|c|}
\hline $\begin{array}{l}\text { Konsep } \\
\text { (Tujuan) }\end{array}$ & $\begin{array}{l}\text { Bobot } \\
\text { Tujuan } \\
\text { (\%) }\end{array}$ & Elemen & $\begin{array}{l}\text { Bobot } \\
\text { Elemen } \\
(\%)\end{array}$ \\
\hline \multirow{5}{*}{$\begin{array}{l}\text { 1. Mendidik } \\
\text { Individu }\end{array}$} & \multirow{5}{*}{30} & E1. Bantuan Pendidikan & 24 \\
\hline & & E2. Penelitian & 27 \\
\hline & & E3. Pelatihan & 26 \\
\hline & & E4. Publikasi & 23 \\
\hline & & Total & 100 \\
\hline \multirow{4}{*}{$\begin{array}{c}2 . \\
\text { Menegakkan } \\
\text { Keadilan }\end{array}$} & \multirow{4}{*}{41} & E5. Return yang adil & 30 \\
\hline & & E6. Fungsi Distribusi & 32 \\
\hline & & E7. Produk Bebas Bunga & 38 \\
\hline & & Total & 100 \\
\hline \multirow{3}{*}{$\begin{array}{c}3 . \\
\text { Memelihara } \\
\text { Kemaslahatan }\end{array}$} & \multirow{3}{*}{29} & E8. Rasio Laba & 33 \\
\hline & & E9. Pendapatan Individu & 30 \\
\hline & & $\begin{array}{l}\text { E10. Rasio investasi di } \\
\text { sektror riil }\end{array}$ & 37 \\
\hline Total & 100 & Total & 100 \\
\hline
\end{tabular}

Sumber: Mohammed \& Taib (2015)

Selanjutnya Mohammed, dkk (2008) mendefinisikan secara operasional konsep maqashid syariah Abu Zahrah yang terdiri dari: Mendidik individu (Tahdzib al-Fard), Menegakkan keadilan (Iqamah al- 'adl), dan Memelihara kemaslahahatan (Jalb al Maslahah) sebagai tujuan yang hendak dicapai oleh bank syariah secara luas. Setiap konsep (tujuan) diterjemahkan menjadi beberapa karakteristik atau dimensi-dimensi. Kemudian masing-masing dimensi memiliki elemen-elemen, dan setiap elemen dapat diukur dengan rasio keuangan bank yang diperoleh dari laporan keuangan perbankan syariah. Menurut Mohammed dkk (2008) Definisi operasional tujuan bank syariah adalah sebagai berikut: 
Tabel 1.2 Definisi Operasional Tujuan Bank Syariah

\begin{tabular}{|c|c|c|c|}
\hline $\begin{array}{l}\text { Konsep } \\
\text { (Tujuan) }\end{array}$ & Dimensi & Elemen & Rasio Kinerja \\
\hline \multirow{4}{*}{$\begin{array}{l}\text { Mendidik } \\
\text { Individu }\end{array}$} & \multirow[t]{2}{*}{$\begin{array}{l}\text { D1. } \\
\text { Memajukan } \\
\text { Pengetahuan }\end{array}$} & $\begin{array}{l}\text { E1. } \\
\text { Bantuan } \\
\text { Pendidikan }\end{array}$ & $\begin{array}{l}\text { R1. Bantuan } \\
\text { Pendidikan/ } \\
\text { Total Beban }\end{array}$ \\
\hline & & $\begin{array}{l}\text { E2. } \\
\text { Penelitian }\end{array}$ & $\begin{array}{l}\text { R2. Beban } \\
\text { Penelitian/ Total } \\
\text { Beban }\end{array}$ \\
\hline & $\begin{array}{l}\text { D2. } \\
\text { Menerapkan } \\
\text { dan } \\
\text { Meningkatkan } \\
\text { Keahlian Baru }\end{array}$ & $\begin{array}{l}\text { E3. } \\
\text { Pelatihan }\end{array}$ & $\begin{array}{l}\text { R3. Beban } \\
\text { Pelatihan/ Total } \\
\text { Beban }\end{array}$ \\
\hline & $\begin{array}{l}\text { D3. } \\
\text { Menciptakan } \\
\text { Kesadaran } \\
\text { akan Bank } \\
\text { Syariah }\end{array}$ & $\begin{array}{l}\text { E4. } \\
\text { Publikasi }\end{array}$ & $\begin{array}{l}\text { R4. Beban } \\
\text { Promosi/ Total } \\
\text { Beban }\end{array}$ \\
\hline \multirow{3}{*}{$\begin{array}{l}\text { Menegakkan } \\
\text { Keadilan }\end{array}$} & $\begin{array}{l}\text { D4. } \\
\text { Pengembalian } \\
\text { yang adil }\end{array}$ & $\begin{array}{l}\text { E5. Return } \\
\text { yang adil }\end{array}$ & $\begin{array}{l}\text { R5. Bagi Hasil } \\
\text { Belum Dibagi/ } \\
\text { Pendapatan } \\
\text { Investasi Bersih }\end{array}$ \\
\hline & $\begin{array}{l}\text { D5. Produk } \\
\text { dan Pelayanan } \\
\text { yang } \\
\text { terjangkau }\end{array}$ & $\begin{array}{l}\text { E6. Fungsi } \\
\text { Distribusi }\end{array}$ & $\begin{array}{l}\text { R6. Pembiayaan } \\
\text { Mudharabah \& } \\
\text { Musyarakah/ } \\
\text { Total } \\
\text { Pembiayaan }\end{array}$ \\
\hline & $\begin{array}{l}\text { D6. } \\
\text { Menghilangkan } \\
\text { unsur-unsur } \\
\text { negatif yang } \\
\text { dapat } \\
\text { menciptakan } \\
\text { ketidakadilan }\end{array}$ & $\begin{array}{l}\text { E7. Produk } \\
\text { Bebas } \\
\text { Bunga }\end{array}$ & $\begin{array}{l}\text { R7. Pendapatan } \\
\text { bebas bunga/ } \\
\text { Total Pendapatan }\end{array}$ \\
\hline \multirow[t]{2}{*}{$\begin{array}{l}\text { Memelihara } \\
\text { Kemaslahatan }\end{array}$} & $\begin{array}{l}\text { D7. } \\
\text { Profitabilitas } \\
\text { Bank }\end{array}$ & $\begin{array}{l}\text { E8. Rasio } \\
\text { Laba }\end{array}$ & $\begin{array}{l}\text { R8. Laba } \\
\text { bersih/Total } \\
\text { Aset }\end{array}$ \\
\hline & D8. & E9. & R9. Zakat Yang \\
\hline
\end{tabular}


Analisis Penilaian Kinerja Bank Syariah Berdasarkan Indeks...

\begin{tabular}{|l|l|l|l|}
\hline & $\begin{array}{l}\text { Redistribusi } \\
\text { Pendapatan \& } \\
\text { Kesejahteraan }\end{array}$ & $\begin{array}{l}\text { Pendapatan } \\
\text { Individu }\end{array}$ & $\begin{array}{l}\text { Dibayarkan/Aset } \\
\text { Bersih }\end{array}$ \\
\cline { 2 - 4 } & $\begin{array}{l}\text { D9. Investasi di } \\
\text { sektor rill }\end{array}$ & $\begin{array}{l}\text { E10. Rasio } \\
\text { investasi di } \\
\text { sektror riil }\end{array}$ & $\begin{array}{l}\text { R10. Investasi } \\
\text { Sektor Riil/Total } \\
\text { Investasi }\end{array}$ \\
\hline
\end{tabular}

Sumber: Mohammed \& Taib (2015)

Pendapatan investasi bersih sejatinya adalah akun Profit Equalization Reserves (PER) berarti sebagian dari pendapatan kotor dari pendapatan pengelolaan dana yang disisihkan, sebelum mengalokasikannya ke bagian mudharib dengan tujuan untuk memberikan return/hasil yang lebih merata kepada pemilik rekening dan pemegang saham. Lihat: Mustafa Omar Mohammed \& Fauziah Md Taib, Developing Islamic Banking Performance Measures Based On Maqasid Al-Shari' ah Framework: Case of 24 Selected Banks, Journal of Islamic Monetary Economics and Finance, August 2015, hal. 63. Sedangkan akun Bagi hasil belum dibagi merupakan hak pihak ketiga yang belum dibagikan kepada pemilik dana Lihat: Wiroso, Akuntansi Transaksi Syariah, (Jakarta: Ikatan Akuntan Indonesia (IAI), 2011), hal. 360. Untuk kepentingan penelitian ini, akun PER diganti dengan akun bagi hasil belum dibagi dengan pertimbangan bahwa atura PER belum diterapkan dalam perbankan syariah di Indonesia.

Mohammed, dkk (2008) juga menjelaskan bahwa untuk menghasilkan indeks maqasid syariah terdapat 3 (tiga) tahapan yaitu:

\section{a. Menentukan Rasio Kinerja}

Tahap pertama yang harus dilakukan adalah menentukan rasio kinerja yang akan digunakan berdasarkan ketersediaan data. Dalam penelitian ini menggunakan 10 rasio keuangan, yaitu:

1) Bantuan Pendidikan/Total Beban (R1)

2) Beban Penelitian/Total Beban (R2)

3) Beban Pelatihan/Total Beban (R3)

4) Beban Promosi/Total Beban (R4)

5) Bagi Hasil Belum Dibagi/Pendapatan Investasi Bersih (R5) 
6) Pembiayaan Mudharabah \& Musyarakah/ Total Pembiayaan (R6)

7) Pendapatan bebas bunga/Total Pendapatan (R7)

8) Laba bersih/Total Aset (R8)

9) Zakat Yang Dibayarkan/Aset Bersih (R9)

10) Investasi Sektor Riil/Total Investasi (R10)

\section{b. Menentukan Rasio Kinerja}

Tahap selanjutnya adalah melakukan operasi perkalian antara dimensi dan rasio kinerja dengan masing-masing bobot. Secara matematis dapat dijelaskan dalam model berikut:

\section{1) Maqasid Pertama (Mendidik Individu)}

$P I(O 1)=W_{1}^{1}\left(E_{1}^{1} \times R_{1}^{1}+E_{1}^{2} \times R_{1}^{2}+E_{1}^{3} \times R_{1}^{3}+E_{1}^{4} \times R_{1}^{4}\right)$

Dimana:

PI $(\mathrm{O} 1)$ = Indikator Kinerja untuk maqasid pertama yaitu Mendidik Individu

$W_{1}^{1}=$ bobot $\mathrm{O} 1$ (Tujuan/maqasid pertama)

$E_{1}^{1}=$ bobot elemen pertama O1

$E_{1}^{2}=$ bobot elemen kedua $\mathrm{O} 1$

$E_{1}^{3}=$ bobot elemen ketiga $\mathrm{O} 1$

$E_{1}^{4}=$ bobot elemen keempat $\mathrm{O} 1$

$R_{1}^{1}=$ rasio dari elemen pertama O1

$R_{1}^{2}=$ rasio dari elemen kedua $\mathrm{O} 1$

$R_{1}^{3}=$ rasio dari elemen ketiga O1

$R_{1}^{4}=$ rasio dari elemen keempat $\mathrm{O} 1$

2) Maqasid Kedua (Menegakkan Keadilan)

$$
P I(O 2)=W_{2}^{2}\left(E_{2}^{1} \times R_{2}^{1}+E_{2}^{2} \times R_{2}^{2}+E_{2}^{3} \times R_{2}^{3}\right)
$$

Dimana:

PI $(\mathrm{O} 2)=$ Indikator Kinerja untuk maqasid kedua yaitu Menegakkan keadilan

$W_{2}^{2}=$ bobot $\mathrm{O} 2$ (Tujuan/maqasid kedua)

$E_{2}^{1}=$ bobot elemen pertama $\mathrm{O} 2$

$E_{2}^{2}=$ bobot elemen kedua $\mathrm{O} 2$

$E_{2}^{3}=$ bobot elemen ketiga $\mathrm{O} 2$

$R_{2}^{1}=$ rasio dari elemen pertama $\mathrm{O} 2$

$R_{2}^{2}=$ rasio dari elemen kedua $\mathrm{O} 2$ 


$$
R_{2}^{3}=\text { rasio dari elemen ketiga } \mathrm{O} 2
$$

\section{3) Maqasid Ketiga (Menghasilkan Kemaslahatan)}

$$
P I(O 3)=W_{3}^{3}\left(E_{3}^{1} \times R_{3}^{1}+E_{3}^{2} \times R_{3}^{2}+E_{3}^{3} \times R_{3}^{3}\right)
$$

Dimana:

PI (O3) = Indikator Kinerja untuk maqasid ketiga yaitu Menghasilkan Kemaslahatan

$W_{3}^{3}=$ bobot $\mathrm{O} 3$ (Tujuan/maqasid ketiga)

$E_{3}^{1}=$ bobot elemen pertama O3

$E_{3}^{2}=$ bobot elemen kedua $\mathrm{O} 3$

$E_{3}^{3}=$ bobot elemen ketiga $\mathrm{O} 3$

$R_{3}^{1}=$ rasio dari elemen pertama $\mathrm{O} 3$

$R_{3}^{2}=$ rasio dari elemen kedua $\mathrm{O} 3$

$R_{3}^{3}=$ rasio dari elemen ketiga $\mathrm{O} 3$

\section{c. Menghitung maqasid Indeks}

Tahap selanjutnya adalah menghitung maqasid indeks dengan rumus sebagai berikut:

$$
\text { Maqasid Indeks = PI (O1) + PI (O2) + PI (O3) }
$$

Dimana:

Maqasid Indeks = nilai indeks maqasid syariah

PI $(\mathrm{O} 1)=$ Total indikator kinerja untuk tujuan pertama yaitu mendidik individu

$\mathrm{PI}(\mathrm{O} 2)=$ Total indikator kinerja untuk tujuan kedua yaitu menegakkan keadilan

$\mathrm{PI}(\mathrm{O} 3)=$ Total indikator kinerja untuk tujuan ketiga yaitu memelihara kemaslahatan

\section{Desain Penelitian}

Penelitian ini merupakan penelitian deskriptif yaitu bertujuan untuk mendeskripsikan nilai indeks maqasid syariah bank umum syariah secara mandiri tanpa membuat hubungan atau perbandingan dengan variabel yang lain (Sugiyono, 2012: 13). Data yang digunakan dalam penelitian ini adalah data sekunder laporan keuangan bank umum syariah di Indonesia yang sudah diaudit oleh auditor 
independen untuk periode yang berakhir tanggal 31 Desember 2015 yang berasal dari situs masing-masing bank umum syariah. Tekhnik sampling dalam penelitian ini menggunakan purposive sampling yaitu tekhnik penentuan sampel dengan pertimbangan/kriteria tertentu (sugiyono, 2008: 122). Kriteria sampel dalam penelitian ini adalah bank umum syariah yang menerbitkan laporan keuangan yang sudah diaudit oleh auditor independen untuk periode yang berakhir tanggal 31 Desember selama tahun 2011-2015 secara konsisten. Sampel dalam penelitian ini adalah 9 (sembilan) bank umum syariah, yaitu: Bank Muamalat, Bank Syariah Mandiri, Bank Syariah Mega, BRI Syariah, Bukopin Syariah, Panin Syariah, BCA Syariah, BNI Syariah, dan Maybank Syariah.

\section{E. Hasil Penelitian}

Maqasid syariah indeks adalah model pengukuran kinerja bank syariah berdasarkan tujuan syariah (maqasid syariah) yang dikembangkan oleh Muhamad, dkk (2008). Pijakan dasar dalam pengembangan Maqasid syariah indeks sebagai ukuran kinerja bank syariah adalah konsep maqasid syariah hasil pemikiran Abu Zahrah yang memiliki 3 (tiga) tujuan, yaitu: mendidik individu, menegakkan keadilan, dan memelihara kemaslahatan.

\section{Mendidik Individu}

Tujuan mendidik individu/PI(O1) memiliki 3 (tiga) dimensi, yaitu: memajukan pengetahuan (D1), menerapkan dan meningkatkan keahlian baru (D2), dan menciptakan kesadaran akan bank syariah (D3). Setiap dimensi dapat diobservasi melalui perilaku yang dapat diukur (elemen). Dimensi memajukan pengetahuan (D1) dapat diukur dengan bantuan pendidikan (E1) dan kegiatan penelitian (E2). Dimensi menerapkan dan meningkatkan keahlian baru (D2) dapat diukur dengan kegiatan pelatihan (E3). Dimensi menciptakan kesadaran 
akan bank syariah (D3) dapat diukur dengan kegiatan publikasi (E4).

Semakin besar bank syariah mengalokasikan dana dalam hal 4 (empat) elemen/indikator, yaitu: bantuan pendidikan (E1), kegiatan penelitian (E2), kegiatan pelatihan (E3), dan kegiatan publikasi (E4), maka menunjukkan bahwa bank syariah semakin fokus dalam pencapaian program mendidik individu. Dan ini merupakan hal yang baik bagi bank syariah dalam hal peningkatan kualitas sumberdaya manusia sehingga pada gilirannya dapat mengedukasi konsumen tentang tujuan, produk, dan pelayanan bank syariah.

Tabel 1.3 Pencapaian Rasio Setiap Elemen

\begin{tabular}{|l|c|c|c|c|}
\hline \multirow{2}{*}{ Nama Bank } & $\begin{array}{c}\text { Bantuan } \\
\text { Pendidikan } \\
\text { (E1) }\end{array}$ & $\begin{array}{c}\text { Kegiatan } \\
\text { Penelitian } \\
\text { (E2) }\end{array}$ & $\begin{array}{c}\text { Kegiatan } \\
\text { Pelatihan } \\
\text { (E3) }\end{array}$ & $\begin{array}{c}\text { Kegiatan } \\
\text { Publikasi } \\
\text { (E4) }\end{array}$ \\
\cline { 2 - 5 } & $\mathbf{R 1}$ & $\mathbf{R 2}$ & $\mathbf{R 3}$ & $\mathbf{R 4}$ \\
\hline Bank Muamalat & 0,00172 & 0,00179 & 0,01715 & 0,04170 \\
\hline Bank Syariah Mandiri & 0,00000 & 0,00045 & 0,01202 & 0,01373 \\
\hline Bank Syariah Mega & 0,00000 & 0,00000 & 0,00201 & 0,00000 \\
\hline BRI Syariah & 0,00000 & 0,00000 & 0,00409 & 0,02923 \\
\hline Bukopin Syariah & 0,00000 & 0,00000 & 0,01668 & 0,01885 \\
\hline Panin Syariah & 0,00068 & 0,00000 & 0,00333 & 0,02043 \\
\hline BCA Syariah & 0,00000 & 0,00000 & 0,01563 & 0,00887 \\
\hline BNI Syariah & 0,00000 & 0,00000 & 0,01806 & 0,05399 \\
\hline Maybank Syariah & 0,00000 & 0,00000 & 0,00188 & 0,00178 \\
\hline
\end{tabular}

Sumber: Data sekunder diolah, 2016

Berdasarkan tabel di atas terlihat bahwa bank syariah yang memperoleh pencapaian tertinggi dalam hal bantuan pendidikan (E1) adalah Bank Muamalat dengan nilai rasio sebesar 0,00172. Pencapaian tertinggi dalam hal kegiatan penelitian (E2) adalah Bank Muamalat dengan nilai rasio sebesar 0,00172. Pencapaian tertinggi dalam hal kegiatan pelatihan (E3) adalah BNI Syariah dengan nilai rasio sebesar 0,01806 dan pencapaian yang terendah adalah Maybank Syariah dengan nilai rasio sebesar 0,00188. Sedangkan pencapaian tertinggi dalam hal 
kegiatan publikasi (E4) adalah BNI Syariah dengan nilai rasio sebesar 0,05399 dan pencapaian terendah adalah Bank Syariah Mega 0,00000.

\section{Menegakkan Keadilan}

Tujuan menegakkan keadilan/PI(O2) memiliki 3 (tiga) dimensi, yaitu: melakukan pengembalian yang adil (D4), menciptakan produk dan pelayanan yang terjangkau (D5), dan menghilangkan unsur-unsur negatif yang dapat menciptakan ketidakadilan (D6). Setiap dimensi dapat diobservasi melalui perilaku yang dapat diukur (elemen). Dimensi melakukan pengembalian yang adil (D4) dapat diukur dengan return yang adil (E5). Dimensi menciptakan produk dan pelayanan yang terjangkau (D5) dapat diukur dengan fungsi distribusi (E6). Dimensi menghilangkan unsur-unsur negatif yang dapat menciptakan ketidakadilan (D6) dapat diukur dengan produk bebas bunga (E7).

Konsep (tujuan) bank syariah menegakkan keadilan berkaitan dengan penegakkan hak-hak dan kewajiban semua pihak yang bertransaksi dengan bank syariah secara adil. Ketika bank syariah membentuk akun bagi hasil belum dibagi berarti sebagian dari pendapatan kotor dari pendapatan pengelolaan dana yang disisihkan, sebelum mengalokasikannya ke bagian mudharib dengan tujuan untuk memberikan return/hasil yang lebih merata kepada pemilik rekening dan pemegang saham. Adanya akun bagi hasil belum dibagi menyebabkan hak orang lain tertahan sehingga menimbulkan ketidakadilan. Misalnya, seorang nasabah yang memutuskan keluar dari bank syariah tidak bisa mendapatkan haknya karena bank menahan sebagian bagi hasil. Padahal uang nasabah tersebut sudah dipakai untuk menyalurkan pembiayaan.

Sedangkan peningkatan pada elemen/indikator fungsi distribusi dan produk bebas bunga menunjukkan bahwa bank syariah berusaha meningkatkan tujuannya dalam hal keadilan sosial ekonomi dan berkontribusi 
secara positif terhadap penghapusan kesenjangan pendapatan dan kekayaan dalam masyarakat. Melalui pembiayaan musyararakah dan mudharabah, bank syariah menciptakan keadilan antara deposan dengan bank syariah, antara bank syariah dengan nasabah pembiayaan dan menghilangkan kedholiman yang bersumber dari sistem bunga.

Tabel 1.4 Pencapaian Rasio Setiap Elemen

\begin{tabular}{|l|c|c|c|}
\hline \multirow{2}{*}{ Nama Bank } & $\begin{array}{c}\text { Return yang } \\
\text { adil (E5) }\end{array}$ & $\begin{array}{c}\text { Fungsi } \\
\text { Distribusi } \\
\text { (E6) }\end{array}$ & $\begin{array}{c}\text { Produk } \\
\text { bebas bunga } \\
\text { (E7) }\end{array}$ \\
\cline { 2 - 4 } & $\mathbf{R 5}$ & $\mathbf{R 6}$ & $\mathbf{R 7}$ \\
\hline Bank Muamalat & 0,01659 & 0,54391 & 0,93976 \\
\hline Bank Syariah Mandiri & 0,00916 & 0,26599 & 0,86181 \\
\hline Bank Syariah Mega & 0,00787 & 0,01405 & 0,56274 \\
\hline BRI Syariah & 0,01434 & 0,37255 & 0,94521 \\
\hline Bukopin Syariah & 0,01566 & 0,48100 & 0,90556 \\
\hline Panin Syariah & 0,02009 & 0,90607 & 0,96863 \\
\hline BCA Syariah & 0,03084 & 0,45336 & 0,97280 \\
\hline BNI Syariah & 0,01904 & 0,19321 & 0,94588 \\
\hline Maybank Syariah & 0,00671 & 0,01674 & 0,97849 \\
\hline
\end{tabular}

Sumber: Data sekunder diolah, 2016

Berdasarkan tabel di atas terlihat bahwa bank syariah yang memperoleh pencapaian tertinggi dalam hal return yang adil (E5) adalah BCA Syariah dengan nilai rasio sebesar 0,03084 dan pencapaian terendah adalah Maybank Syariah dengan nilai rasio sebesar 0,00671. Pencapaian tertinggi dalam hal fungsi distribusi (E6) adalah Bank Panin Syariah dengan nilai rasio sebesar 0,90607 dan pencapaian terendah adalah Bank Syariah Mega dengan nilai rasio sebesar 0,01405. Pencapaian tertinggi dalam hal produk bebas bunga (E7) adalah Maybank Syariah dengan nilai rasio sebesar 0,97849 dan pencapaian yang terendah adalah Bank Mega Syariah dengan nilai rasio sebesar 0,56274 . 


\section{Memelihara Kemaslahatan}

Tujuan memelihara kemaslahatan/PI(O3) memiliki 3 (tiga) dimensi, yaitu: menghasilkan profitabilitas bank (D7), melakukan redistribusi pendapatan \& kesejahteraan (D8), dan melakukan investasi di sektor riil (D9). Setiap dimensi dapat diobservasi melalui perilaku yang dapat diukur (elemen). Dimensi menghasilkan profitabilitas bank (D7) dapat diukur dengan rasio laba (E8). Dimensi melakukan redistribusi pendapatan \& kesejahteraan (D8) dapat diukur dengan pendapatan individu (E9). Dimensi melakukan investasi di sektor riil (D9) dapat diukur dengan rasio investasi di sektor riil (E10).

Konsep (tujuan) bank syariah menghasilkan kemaslahatan berkaitan dengan kemaslahatan umum, yaitu keuntungan dan manfaat yang tidak hanya dirasakan oleh bank syariah tetapi juga oleh sekelompok masyarakat. Semakin tinggi rasio laba berarti menunjukkan bahwa bank syariah menikmati maslahah secara finansial, selain itu dapat juga meningkatkan pajak bank syariah yang berkontribusi dalam proyek pembangunan pemerintah dan pelayanan sosial yang berdampak pada kesejahteraan masyarakat. Peningkatan pada zakat yang dibayarkan juga berdampak pada peningkatan transfer pendapatan dan kekayaan kepada orang-orang miskin yang membutuhkan sehingga mengurangi kesenjangan pendapatan. Peningkatan pada rasio investasi pada sektor riil menunjukkan bahwa bank syariah secara langsung berinvestasi pada sektor ekonomi riil, seperti: sektor pertanian, pertambangan, perikanan, konstruksi, manufaktur, usaha keci dan menengah. Karena sektor riil berdampak langsung secara luas pada populasi masyarakat. 
Tabel 1.5 Pencapaian Rasio Setiap Elemen

\begin{tabular}{|l|c|c|c|}
\hline \multicolumn{1}{|c|}{ Nama Bank } & $\begin{array}{c}\text { Rasio Laba } \\
\text { (E8) }\end{array}$ & $\begin{array}{c}\text { Pendapatan } \\
\text { Individu (E9) }\end{array}$ & $\begin{array}{c}\text { Investasi di } \\
\text { sektor riil } \\
\text { (E10) }\end{array}$ \\
\cline { 2 - 4 } & $\mathbf{R 8}$ & $\mathbf{R 9}$ & $\mathbf{R 1 0}$ \\
\hline Bank Muamalat & 0,00130 & 0,00009 & 0,89600 \\
\hline Bank Syariah Mandiri & 0,00412 & 0,00016 & 0,86680 \\
\hline Bank Syariah Mega & 0,00220 & 0,00009 & 0,90195 \\
\hline BRI Syariah & 0,00506 & 0,00001 & 0,88192 \\
\hline Bukopin Syariah & 0,00477 & 0,00000 & 0,97164 \\
\hline Panin Syariah & 0,00751 & 0,00031 & 0,94401 \\
\hline BCA Syariah & 0,00539 & 0,00000 & 0,98342 \\
\hline BNI Syariah & 0,00993 & 0,00039 & 0,88319 \\
\hline Maybank Syariah & $-0,16886$ & 0,00000 & 0,75932 \\
\hline
\end{tabular}

Sumber: Data sekunder diolah, 2016

Berdasarkan tabel di atas terlihat bahwa bank syariah yang memperoleh pencapaian tertinggi dalam hal rasio laba (E8) adalah Bank Muamalat dengan nilai rasio sebesar 0,00993 dan pencapaian yang terendah adalah Maybank Syariah dengan nilai rasio sebesar -0,16886. Pencapaian tertinggi dalam hal pendapatan individu (E9) adalah BNI Syariah dengan nilai rasio sebesar 0,00039. Pencapaian tertinggi dalam hal investasi di sektor riil (E10) adalah BCA Syariah dengan nilai rasio sebesar 0,98342 dan pencapaian yang terendah adalah Maybank Syariah dengan nilai rasio sebesar 0,75932.

\section{Indeks Maqasid Syariah}

Sedangkan hasil perhitungan masing-masing tujuan dan indeks maqasid syariah bank syariah di Indonesia tahun 2015 adalah sebagai berikut:

Tabel 1.6 Pencapaian Indeks Maqasid Syariah Bank Syariah Tahun 2015

\begin{tabular}{|c|c|c|c|c|c|}
\hline \multirow{2}{*}{$\begin{array}{c}\text { Nama } \\
\text { Bank }\end{array}$} & $\begin{array}{c}\text { Mendidik } \\
\text { Individu }\end{array}$ & $\begin{array}{c}\text { Menegakkan } \\
\text { Keadilan }\end{array}$ & $\begin{array}{c}\text { Memelihara } \\
\text { Kemaslahatan }\end{array}$ & $\begin{array}{c}\text { Maqasid } \\
\text { Indeks }\end{array}$ & $\begin{array}{c}\text { Ran } \\
\text { king }\end{array}$ \\
\cline { 2 - 4 } & PI(O1) & PI(O2) & PI(O3) & \\
\hline $\begin{array}{l}\text { Bank } \\
\text { Muamalat }\end{array}$ & 0,00448 & 0,21982 & 0,09627 & 0,32057 & 3 \\
\hline
\end{tabular}




\begin{tabular}{|l|c|c|c|c|c|}
\hline $\begin{array}{l}\text { Bank } \\
\text { Syariah } \\
\text { Mandiri }\end{array}$ & 0,00192 & 0,17029 & 0,09342 & 0,26563 & 7 \\
\hline $\begin{array}{l}\text { Bank } \\
\text { Syariah } \\
\text { Mega }\end{array}$ & 0,00016 & 0,09049 & 0,09700 & 0,18765 & 9 \\
\hline $\begin{array}{l}\text { BRI } \\
\text { Syariah }\end{array}$ & 0,00234 & 0,19791 & 0,09512 & 0,29537 & 5 \\
\hline $\begin{array}{l}\text { Bukopin } \\
\text { Syariah }\end{array}$ & 0,00260 & 0,20612 & 0,10471 & 0,31343 & 4 \\
\hline $\begin{array}{l}\text { Panin } \\
\text { Syariah }\end{array}$ & 0,00172 & 0,27226 & 0,10204 & 0,37602 & 1 \\
\hline $\begin{array}{l}\text { BCA } \\
\text { Syariah }\end{array}$ & 0,00183 & 0,21484 & 0,10604 & 0,32271 & 2 \\
\hline $\begin{array}{l}\text { BNI } \\
\text { Syariah }\end{array}$ & 0,00513 & 0,17506 & 0,09575 & 0,27594 & 6 \\
\hline $\begin{array}{l}\text { Maybank } \\
\text { Syariah }\end{array}$ & 0,00027 & 0,15547 & 0,06532 & 0,22106 & 8 \\
\hline
\end{tabular}

Sumber: Data sekunder diolah, 2016

Berdasarkan tabel di atas terlihat bahwa bank syariah yang memperoleh pencapaian tertinggi tujuan pertama maqasid syariah mendidik individu/PI(O1) adalah BNI Syariah sebesar 0,00513 dan pencapaian yang terendah adalah Bank Syariah Mega sebesar 0,00016. Pencapaian tertinggi tujuan kedua maqasid syariah menegakkan keadilan/PI(O2) adalah Bank Panin Syariah sebesar 0,27226 dan pencapaian yang terendah adalah Bank Syariah Mega sebesar 0,09049. Pencapaian tertinggi tujuan ketiga maqasid syariah memelihara kemaslahatan/PI(O3) adalah BCA Syariah sebesar 0,10604 dan pencapaian yang terendah adalah Maybank Syariah sebesar 0,06532. Sedangkan pencapaian indeks maqasid syariah yang tertinggi tahun 2015 adalah Bank Panin Syariah sebesar 0,37602 dan pencapaian indeks maqasid syariah yang terendah adalah Bank Mega Syariah sebesar 0,18765. 
Analisis Penilaian Kinerja Bank Syariah Berdasarkan Indeks...

\section{F. Simpulan}

Analisis penilaian kinerja bank umum syariah di Indonesia berdasarkan indeks maqasid syariah menghasilkan peringkat sebagai berikut: 1) Bank Panin Syariah, 2) BCA Syariah, 3) Bank Muamalat, 4) Bukopin Syariah, 5) BRI Syariah, 6) BNI Syariah, 7) Bank Syariah Mandiri, 8) Maybank Syariah, dan 9) Bank Mega Syariah. 


\section{DAFTAR PUSTAKA}

Al-Shatibi, Abu Ishaq. al-Muwafaqat Fi Ushul al-Syari' ah. Tunis: Matba' a Dawlatiyya, 1975

Antonio, Muhammad Syafi' I, dkk. An Analysis of Islamic Banking Performance: Maqashid Index Implementation in Indonesia and Jordania, Journal of Islamic Finance, Vol. 1, No. 1, (2012), hal. 012-029

Asmawi, Studi Hukum Islam: Dari Tekstualis-Rasionalis Sampai Rekonsiliatif, Yogyakarta: Terasm 2012

Auda, Jasser. Maqasid Al-Shariah As Philosophy of Islamic Law: A Systems Approach, Herndon-London: The International Institute of Islamic Thought, 2008

Badreldin, Ahmed Mohamed. Measuring The Performance of Islamic Banks by Adapting Conventional Ratios, Working Paper Series 16, (German University in Cairo: Faculty of Management Technology, Oktober 2009), hal. $1-26$

Bashir, Abdel-Hameed M. Assessing The Performance of Islamic Banks: Some Evidence from The Middle East, Topics in Middle Eastern and North African Economies, Electronic Journal, Volume 3, Middle East Economic Association and Loyola Universtiy Chicago, September, 2001, http://www.luc.edu/orgs/meea/

Choong, Yap Voon Chan Kok Thim, and Bernet Talasbek Kyzy, Performance of Islamic Commercial Banks In Malaysia: An Empirical Study, Journal of Islamic Economics, Banking and Finance, Vol. 8, No.2, April-June 2012, hal. $67-80$

Dusuki, Asyraf Wajdi. Understanding The Objectives of Islamic Banking: A Survey Stakeholder Perspectives, International Journal of Islamic and Middle Eastern 
Finance and Management, Vol. 1, No.2, 2008, hal. 132148

Forum Kajian Ilmiah (FKI) Ahla Shuffah 103, Tafsir Maqashidi: Kajian Tematik Maqashid al-Syari' ah, Kediri: Lirboyo Press, 2013

Hidayat, Sutan Emir \& Abduh, Muhamad. Does Financial Crisis Give Impact on Bahrain Islamic Banking Performance? A Panel Regression Analysis, International Journal of Economics and Finance, Vol. 4, No. 7, July 2012, hal. 79-87

Jaya, Asafari. Konsep Maqashid al-Syari' ah Menurut alSyathibi, Jakarta: Raja Grafindo Persada, 1996

Jazil, Thuba and Syahruddin. The Performance Measures of Selected Malaysian and Indonesian: Islamic Banks Based on The Maqasid al-Shari' ah Approach, Ijtihad, Vol. 7, No. 2 (2013), hal. 279-301

Mohammad, Mustafa Omar and Shahwan, Syahidawati. The Objective of Islamic Economic and Islamic Banking in Light of Maqasid Al-Shariah: A Critical Review, MiddleEast Journal of Scientific Research 13 (Research in ContemporaryIslamic Finance and Wealth Management): 75-84, 2013

Mohammed, Mustafa Omar, dkk. The Performance Measures of Islamic Bankinng Based on The Maqasid Framework, paper, prasented at the IIUM International Accounting Conference (INTAC IV) held at Putra Jaya Marroitt, 25 June 2008, hal. 1-29

Mohammed, Mustafa Omar \& Taib, Fauziah Md. Developing Islamic Banking Performance Measures Based On Maqasid Al-Shari' ah Framework: Case of 24 Selected Banks, Journal of Islamic Monetary Economics and Finance, August 2015, hal. 55-77 
Shidiq, Ghofar. Teori Maqashid Al-Syari' ah Dalam Hukum Islam, Sultan Agung, Vol.XLIV, No.118 Juni-Agustus 2009

Sugiyono, Metode Penelitian Bisnis (Pendekatan Kuantitatif, Kualitatif dan R\&D), Bandung: Alfabeta, 2008

----------, Metode Penelitian Bisnis, Bandung: Alvabeta, 2012

Wiroso, Akuntansi Transaksi Syariah, Jakarta: Ikatan Akuntan Indonesia (IAI), 2011

Zahrah, Muhammad Abu. Ushul al-Fiqh, Kairo: Dar al-Fikr alArabi, 1997

Zeitun, Rami. Determinant of Islamic and Conventional Banks Performance in GCC Countries Using Panel Data Analysis, Global Economy and Finance Journal, Vol. 5, No. 1, March 2012, hal. 53-72 